\title{
DISTRIBUTION OF TREE SPECIES IN A GEOMORPHOLOGICAL AND PEDOLOGICAL GRADIENT OF SUBMONTANE SEMIDECIDUAL SEASONAL FOREST IN THE VICINITY OF RIO DOCE STATE PARK, MINAS GERAIS ${ }^{1}$
}

\author{
Priscila Bezerra de Souza², João José Lelis ${ }^{3}$, Carlos Ernesto Gonçalves Reynaud Schaefer ${ }^{4}$, Agostinho \\ Lopes de Souza ${ }^{5}$ e João Augusto Alves Meira Neto ${ }^{6}$
}

\begin{abstract}
The objective of this study was to test the hypothesis that the distribution of tree species in a fragment of submontane seasonal semideciduous forest, a buffer zone in the Parque Estadual do Rio Doce, Minas Gerais, is influenced by geomorphological and weather and soil variables, therefore it can represent a source of information for the restoration of degraded areas where environmental conditions are similar to those of the study area. A detailed soil survey was conducted in the area by sampling three soil profiles per slope segment, totaling 12 profiles. To sample the topsoil, four composite samples were collected from the $10-20 \mathrm{~cm}$ layers in each topographic range totaling 16 composite samples. In the low ramp and the lower and upper concave slopes, the texture ranged from clay to sandy-clay. The soil and topographic gradient was characterized by changes in the soil physical-chemical properties. The soil in the $10-20 \mathrm{~cm}$ sampled layer was sandier, slightly more fertile and less acid in the low ramp than the clayer soil, nutrient-poor and highly acid soil at the top. The soil conditions in the lower and upper slope of the sampled layers, in turn, were intermediate. The $\mathrm{P}$ levels were limiting in all soils. The species distribution along the topographic gradient was associated with variations in chemical fertility, acidity and soil texture. The distribution of Pera leandri, Astronium fraxinifolium, Pouteria torta, Machaerium brasiliense and Myrcia rufipes was correlated with high aluminum levels and to low soil fertility and these species may be indicated for restoration of degraded areas on hillsides and hilltops in regions where environmental conditions are similar. The distribution of Pouteria venosa, Apuleia leiocarpa and Acacia polyphylla was correlated with the less acid and more fertile soil in the environment of the low ramps, indicating the potential for the restoration of similar areas.
\end{abstract}

Keywords: Soil-vegetation, Topographic gradient e Geomorphological gradient.

\section{DISTRIBUIÇ̃̃O DE ESPÉCIES ARBÓREAS EM GRADIENTE GEOMORFOLÓGICO E PEDOLÓGICO DE FLORESTA ESTACIONAL SEMIDECIDUAL SUBMONTANA, ZONA DE AMORTECIMENTO DO PARQUE ESTADUAL DO RIO DOCE, MG}

\begin{abstract}
RESUMO - Este estudo teve como objetivos testar a hipótese de que a distribuição de espécies arbóreas num fragmento de Floresta Estacional Semidecidual Submontana, Zona de Amortecimento do Parque Estadual do Rio Doce, MG, é influenciada por variáveis geomorfológicas e edáficas e, dessa forma, fornecer subsídios para a recuperação de áreas degradadas em condições ambientais similares às da área de estudo. Foi realizado um levantamento detalhado de solos na área, com a abertura de perfis, sendo três em cada faixa (Rampa baixa, Baixa encosta côncava, Alta encosta côncava e Topo), totalizando 12 perfis. Nas coletas superficiais de solo foram colhidas quatro amostras compostas, na profundidade de $10-20 \mathrm{~cm}$ em cada faixa topográfica
\end{abstract}

\footnotetext{
${ }^{1}$ Recebido em 26.04.2010 e aceito para publicação em 28.05.2012.

${ }^{2}$ Universidade Federal do Tocantins, Departamento de Engenharia Florestal. E-mail: <priscilauft@uft.edu.br>.

${ }^{3}$ Universidade Federal de Viçosa, Departamento de Solos. E-mail: <jjlelis@ yahoo.com.br>.

${ }^{4}$ Universidade Federal de Viçosa, Departamento de Solos. E-mail: <carlos.schaefer@ufv.br>.

${ }^{5}$ Universidade Federal de Viçosa, Departamento de Engenharia Florestal. E-mail: <alsouza@ufv.br>.

${ }^{6}$ Universidade Federal de Viçosa, Departamento de Biologia Vegetal. E-mail: <j.meira@ufv.br>.
} 
(Rampa baixa, Baixa encosta côncava, Alta encosta côncava e Topo), totalizando 16 amostras compostas. A partir dessas coletas foi realizada a caracterização química e granulométrica de cada amostra. Os solos foram classificados de acordo com o novo Sistema Brasileiro de Classificação de Solos. Os resultados da análise textural do solo na posição topográfica de Topo indicaram que a textura desse solo era muito argilosa. Nas posições topográficas Rampa baixa, Baixa encosta côncava e Alta encosta côncava, a textura variou de argilosa a argiloarenosa. O gradiente pedológico e topográfico é caracterizado por alterações nas propriedades físico-químicas do solo, sendo este amostrado $(10-20 \mathrm{~cm})$ na Rampa baixa mais arenosa, pouco mais fértil e menos ácida, em comparação com a do solo no Topo, mais argiloso, com teores baixos de macronutrientes e elevada acidez. A Baixa Encosta e Alta Encosta dos solos amostrados (a 10-20 cm), por sua vez, apresentaram condições edáficas intermediárias. Os teores de P eram limitantes em todos os solos. A distribuição das espécies ao longo do gradiente topográfico é associada com as variações da fertilidade química, acidez e textura do solo. Pera leandri, Astronium fraxinifolium, Pouteria torta, Machaerium brasiliense, Myrcia rufipes, Swartzia apetala e Lecythis lurida apresentaram suas distribuições correlacionadas com os teores elevados de alumínio e baixa fertilidade do solo, podendo ser indicadas para restauração de áreas degradadas em encostas e topos de morros em regiões com condições ambientais semelhantes às da área estudada. Pouteria venosa, Apuleia leiocarpa e Acacia polyphylla tiveram suas distribuições correlacionadas com solo menos ácido e mais fértil do ambiente mais plano de rampas, apresentando potencial para restauração de áreas similares.

Palavras-chave: Solo-vegetação, Gradiente topográfico and Geomorfológico.

\section{INTRODUCTION}

In the last decades, there has been a considerable progress in studies of forest communities, mainly in view of their importance for the conservation of biological diversity. In addition, this has progressively becoming more essential due to the disordered process of land occupation which, in the most divergent regions of the country, has split contiguous forest formations into fragments. Moreover, the remaining areas are usually located on private estates and exposed to countless disturbances (OLIVEIRA FILHO et al., 1994a).

Several studies have shown that one of the main factors in the floristic composition and forest structure is the effect of environmental heterogeneity, which can be act even in small fragments (OLIVEIRA FILHO et al., 1994b, 1998; DURIGAN et al., 2000; BOTREL et al., 2002; CARVALHO et al., 2005; ROCHA et al., 2005). This heterogeneity is a result of the diversity of factors interacting in the communities. Due to the response of the species to these factors, each location has its particular features as well as characteristics in common with other locations. Trends that can answer a few questions and raise several others can be observed acting as a driving force towards further studies (RODRIGUES et al., 2007).

At a local scale, the topography of tropical forests is considered the most essential variable in spatial distribution and structure, because it generally represents changes in soil properties, mainly in terms of groundwater

Revista Árvore, Viçosa-MG, v.36, n.4, p.707-718, 2012 regime and fertility. The correlation between tree species distribution, soil variables and topography has been successively demonstrated in several studies on tropical forests (OLIVEIRA FILHO et al., 2001; ESPÍRITO SANTO et al., 2002; SOUZA et al., 2003; CARVALHO et al., 2005; FERREIRA JR. et al., 2007).

In fragments of seasonal semideciduous forest in regions with hilly or mountainous landscape changes in the distribution of tree vegetation along the topographic gradients and their relationships with edaphic factors need to be analyzed to define conservation and management strategies of these remnant forests as well as of forest restoration in already degraded areas (MARTINS et al., 2003).

In the region of the Vale do Rio Doce, in the northern Zona da Mata of the state of Minas Gerais, a series of studies has been conducted in forest fragments, to increase the understanding of the ecology of native tree species aiming at selecting species that will be used in subsequent efforts of revegetation and identification (DRUMOND AND MEIRA-NETO, 1999; LOMBARDI and GONÇALVES, 2000; LOPES et al., 2002; BORTOLUZZI et al., 2004). Basically, these studies determine the preferential habitats of species growth and establishment and identify correlations between floristics and structure of the tree community.

The objective of this study was to test the hypothesis that the distribution of tree species in a fragment of submontane seasonal semideciduous forest, in the buffer 
zone of the Parque Estadual do Rio Doce, MG, is influenced by geomorphological and edaphic variables to provide relevant information for the restoration of degraded areas environmentally similar to those of the study area.

\section{MATERIALAND METHODS}

\subsection{Study area}

The study was conducted in a 1,500-ha forest fragment in Dionísio-MG $\left(19^{\circ} 48^{\prime} \mathrm{S}\right.$ and $42^{\circ} 31^{\prime} \mathrm{W}$, at approximately $450 \mathrm{~m}$ asl), which is a buffer zone in the Parque Estadual do Rio Doce, Minas Gerais. The climate in the region is humid subtropical, with a rainy summer and dry winter season, from April through September. The average annual rainfall is $1,450 \mathrm{~mm}$ and the annual temperature ranges from 20 to $23^{\circ} \mathrm{C}$ (GILHUIS, 1986). The soils are mostly Red-Yellow and Haplic Cambisols, both dystrophic, acidic and with low natural fertility, a common characteristic of soils in the region of Vale do Rio Doce. The relief is hilly to strongly hilly and the soil texture is from clay to very clay (LOMBARDI; GONÇALVES, 2000). The fragment vegetation was characterized as a submontane seasonal semideciduous forest (VELLOSO et al., 1991), growing on the geomorphological gradients, ie, the topographic positions: low ramp, low concave slope, concave slope and hill top.

\subsection{Vegetation sampling}

The plot method (MUELLER-DOMBOIS; ELLENBERG, 1974) was used in this study. One hundred and twenty contiguous $10 \times 10 \mathrm{~m}$ plots were determined, corresponding to a total sampling area of $12,000 \mathrm{~m}^{2}$, or 1.20 ha, distributed over the following topographic units: low ramp, lower concave slope, upper concave slope and hill top. Four groups of 30 contiguous plots were marked along the slope: plots $1-30$ in the low ramp, 31 - 60 in the lower concave slope, 61 - 90 in the upper concave slope and $91-120$ on the top.

All trees with circumference greater than or equal to $10 \mathrm{~cm}, 1.30 \mathrm{~m}$ from the ground $(\mathrm{CBH})$ were considered. The botanical material was identified based on the literature and by comparison in the Herbarium in the Department of Plant Biology at the Universidade Federal de Viçosa. The species index was updated with the specific binomens of the Royal Botanic Gardens, Kew (1993) and Missouri Botanical Garden Web site (available at: http://
www.mobot.org/W3T/search/vast.html) in June 2007. The classification system APG II was used (SOUZA; LORENZI, 2005).

\subsection{Soil analysis}

A detailed soil survey was conducted in the area, with the opening of three profiles per range (low ramp, lower concave slope, and upper concave slope hill top), totaling 12 profiles. After that, the chemical properties and particle size distribution of each horizon were characterized. The soils were classified according to the new Brazilian Soil Classification System (EMBRAPA, 1999).

Based on the created map, four composite samples were collected at a depth of $10-20 \mathrm{~cm}$ in each topographic range, to measure the soil chemical properties in the plots, totaling 16 composite samples. The definition of these four ranges was based on soil mapping in the field, where four plots of each class were selected in which composite sampling was randomly performed, as follows: plots 1 - 4 in the low ramp, 5-8 in the lower concave slope, 9 - 12 in the upper concave slope and $13-16$ at the hill top. Analyses were performed in the laboratory of the soil department of the UFV. The following soil characteristics were determined: $\mathrm{pH}$ in water, total organic carbon, phosphorus $(\mathrm{P})$, potassium $(\mathrm{K})$, calcium $\left(\mathrm{Ca}^{+2}\right)$, magnesium $(\mathrm{Mg})$, aluminum $\left(\mathrm{Al}^{+3}\right)$, potential acidity $(\mathrm{H}+\mathrm{Al})$, sum of bases $(\mathrm{SB})$, cation exchange capacity [CTC $(\mathrm{t})]$ effective cation exchange capacity at $\mathrm{pH}$ 7.0 $(\mathrm{T})$, base saturation index $(\mathrm{V}), \mathrm{Al}$ saturation index $(\mathrm{m})$ and soil size fractions (sand, silt and clay) to define the texture class (EMBRAPA, 1997).

The Monte Carlo permutation (randomization) test was used to evaluate the significance level of the main axis of canonical ordination, to assess the probability of matches found in the relationships among environmental variables. The coefficients of regression between the chemical and physical characteristics of the profiles studied in the different altitude ranges low ramp, lower concave slope, upper concave slope, and hill top were tested to show the significance of the correlation of the curve trend line.

\subsection{Ordination of soil and vegetation data}

To test the hypothesis that species distribution varies along the geomorphological and pedological gradient, the vegetation data were analyzed together with data from soil analysis, based on the canonical 
correlation analysis (CCA) (TER BRAAK, 1987). The CCA provides a direct ordination analysis of the gradients, explaining the species distribution in relation to environmental variables (TER BRAAK, 1987; TER BRAAK, 1995).

Two matrices were constructed for this analysis: a vegetation matrix containing the values of species density in the plots, and an environmental matrix containing the soil data. The analysis was performed by using the program PC-ORD (MCCUNE; MEFFORD, 1999). Only species with five or more trees were considered in the total survey, since in ordination techniques, rare species hardly influence results $(\mathrm{GAUCH}$, 1982) but impair the interpretation of CCA. Therefore, the vegetation matrix consisted of 27 tree species and the environmental matrix of the variables $\mathrm{P}, \mathrm{K}, \mathrm{Ca}, \mathrm{Mg}$, Al, fine sand, coarse sand, and clay.

\section{RESULTS}

\subsection{Physicochemical soil characterization}

The results of textural analysis of soil ranged from top topographic position. In the plots of the lower ramp and lower and upper concave slopes, the texture ranged from clay to sandy-clay.

The results of soil chemical analysis are presented in Table 1 . In relation to $\mathrm{pH}, \mathrm{H}+\mathrm{Al}, \mathrm{m}$, all soils were acidic and had a clear pattern of variation along the topographic gradient. But the Al content increased from the low ramp to the top, indicating greater soil acidity at the hill top than in the low ramp, and intermediate contents in the upper and lower concave slope positions.

The levels of extractable P by Mehlich - 1 were extremely low and represent the chemical poverty of the system and the dependence on biocycling for the maintenance of the forest biomass.

\subsection{Ordination of soil and vegetation data}

The results of canonical correlation analysis 10$20 \mathrm{~cm}$ are presented in Figure 1 and in Table 2. The scores of species and their respective abbreviations are given in Table 3 .

The eigenvalues for the first two axes of canonical ordination sampled in topsoils $10-20 \mathrm{~cm}$ were 0.323 and 0.303 with the first axis explaining $16.3 \%$ of the total variance of the data and the second $13.9 \%$.
The permutation test of Monte Carlo, for the first two ordination axes sampled in soils $10-20 \mathrm{~cm}$, showed that the correlations between species abundance in plots and the soil variables were significant at $5 \%$ probability.

The species ordination on the first and second axes of CCA (Figure 1) sampled in surface soil (10$20 \mathrm{~cm}$ ) suggests that species such as Machaerium brasiliense, Swartzia apetala, Lecythis lurida, Astronium fraxinifolium, Pera leandri, Pouteria torta, Myrcia rufipes, Myrcia tijucensis and Jacaranda macrantha tend to be more abundant in plots on the top, with more loamy soil, higher Al content, higher $\mathrm{Mg}$ and $\mathrm{K}$ concentrations and greater depth.

On the opposite far end of the gradient, another group of species was shown to be correlated with better conditions of chemical fertility and more sandy soil texture, including Pouteria venosa, Apuleia leiocarpa, Acacia polyphylla, Tapirira guianensis, Miconia calvescens, Myrcia fallax, Newtonia contorta, Siparuna guianensis, Licania octandra, Xylopia aromatica, and Xylopia sericea, among others (Figure 1). It is important to note that these species occur on the low ramp and on the lower and upper concave slopes.

However, the ordination of the plots on the first and second axis (Figure 1) sampled in the soil surface $(10-20 \mathrm{~cm})$ showed a soil gradient where the plots ( 1 - 4) of the low ramp were correlated with more sandy soil. In this same direction of axis 1 , the plots of the top position (plots 13,14, 15 and 16) were correlated with soils with higher clay and Al content.

The set of results shows that despite being little evident, the changes in the soil chemical fertility and texture over the topographic gradient may influence the tree vegetation distribution in the gradient, especially between the topographic positions low ramp and top, which confirms the initial study hypothesis.

\subsection{Analysis of environmental variables and the Pearson Correlation (r)}

The chemical and physical attributes of the profiles in the four ranges identified in the fragment of the Mata do Mumbaça (low ramp, lower and upper concave slope, and hill top) classified soil fertility in the low ramp as better, the Dystrophic Cambisols in the lower and upper concave slope as poorer and the Dystrophic Latossolo Amarelo on the top as poorest. 
The first soil class found in the low ramp includes relatively young and rich soil, also dystrophic Haplic Cambisols, where the landscape has a flat to slightly inclined topography, with consequently more concentrated and fertile environments. In a more detailed evaluation of the chemical characteristics along the diagnostic profile of this soil class, it was observed that only in the $30-50 \mathrm{~cm}, 50-70 \mathrm{~cm}$ and $70-100 \mathrm{~cm}$ layers base saturation (V) is above $20 \%$, featuring a richer environment only in deeper layers, while the material of origin was naturally very leached.

The lower and upper slope are composed of dystrophic Haplic Cambisols located on the concave and steeper slopes, just below the dystrophic Latossolo Amarelo of the top and uphill from the richer soils in the low ramp. These ranges of dystrophic Cambisols (lower and upper slope) represent a concave and ascending environment, intermediate between the dystrophic Latossolo Amarelo of the hill top, uphill from the Cambisols of the low ramp, slightly more fertile in terms of soil chemical fertility and water content.
Table 2 - Correlation coefficient among edaphic variables from the subsurface soil $(10-20 \mathrm{~cm})$ and the two main discriminating axis obtained from the canonical correspondence analysis. Data from Submontane, semideciduous forest (Mata do Mumbaça, Dionísio, Minas Gerais State).

Tabela 2 - Coeficientes de correlação entre as variáveis edáficas amostradas em solos superficiais $(10-20 \mathrm{~cm})$ e os dois primeiros eixos de ordenação da análise de correspondência canônica. Dados obtidos numa Floresta Estacional Semidecidual Submontana, Mata do Mumbaça, Dionísio-MG.

\begin{tabular}{lcc}
\hline Edaphic Variables & Axes 1 & Axes 2 \\
\hline Phosphorus (P) & 0.168 & 0.472 \\
Potassium (K) & 0.552 & -0.117 \\
Calcium (Ca) & 0.167 & -0.228 \\
Magnesium (Mg) & 0.459 & -0.308 \\
Aluminum (Al) & 0.586 & -0.552 \\
Coarse Sand & -0.304 & 0.844 \\
Fine sand & 0.108 & 0.762 \\
Clay & 0.496 & -0.737 \\
\hline
\end{tabular}

Table 1 - Chemical and physical characteristics of soil at 10- $20 \mathrm{~cm}$, collected from 16 plots under Submontane, semideciduous forest (Mata do Mumbaça, Dionísio, Minas Gerais State).

Tabela 1 - Características químicas e físicas do solo na profundidade de 10-20 cm coletado de 16 perfis sob Floresta Estacional Semidecidual Submontana, Mata do Mumbaça, Dionísio-MG.

\begin{tabular}{|c|c|c|c|c|c|c|c|c|c|c|c|c|c|c|}
\hline \multirow[t]{2}{*}{ Plots } & & \multirow[t]{2}{*}{$\begin{array}{l}\text { Horizon } \\
\qquad(\mathrm{cm})\end{array}$} & \multirow{2}{*}{$\frac{\mathrm{pH}}{\mathrm{H}_{2} \mathrm{O}}$} & $\mathrm{P}$ & $\mathrm{K}$ & $\mathrm{Ca}$ & $\mathrm{Mg}$ & Al & $\mathrm{H}+\mathrm{Al}$ & SB & $\mathrm{t}$ & $\mathrm{T}$ & V & $\mathrm{m}$ \\
\hline & & & & \multicolumn{2}{|c|}{$\left(\mathrm{mg} / \mathrm{kg}^{-1}\right)$} & \multicolumn{7}{|c|}{$\longrightarrow\left(\mathrm{cmol}_{\mathrm{c}} / \mathrm{kg}^{-1}\right) \longrightarrow$} & \multicolumn{2}{|c|}{$(\%)$} \\
\hline \multirow{4}{*}{ Low Ramp } & 1 & $(10-20)$ & 4.01 & 2.4 & 24 & 0.24 & 0.06 & 1.25 & 2.2 & 0.36 & 1.61 & 2.56 & 14.1 & 77.6 \\
\hline & 2 & $(10-20)$ & 4.12 & 1.1 & 20 & 0.22 & 0.05 & 0.87 & 2.4 & 0.32 & 1.19 & 2.72 & 11.8 & 73.1 \\
\hline & 3 & $(10-20)$ & 4.09 & 1.2 & 20 & 0.23 & 0.04 & 0.87 & 1.9 & 0.32 & 1.19 & 2.22 & 14.4 & 73.1 \\
\hline & 4 & $(10-20)$ & 4.07 & 1.2 & 19 & 0.21 & 0.04 & 0.87 & 1.6 & 0.3 & 1.17 & 1.9 & 15.8 & 74.4 \\
\hline \multirow{4}{*}{$\begin{array}{l}\text { Low } \\
\text { Concave } \\
\text { Slope }\end{array}$} & 5 & $(10-20)$ & 4.13 & 1.5 & 20 & 0.23 & 0.05 & 0.87 & 1.9 & 0.33 & 1.2 & 2.23 & 14.8 & 72.5 \\
\hline & 6 & $(10-20)$ & 4.16 & 1.7 & 20 & 0.23 & 0.05 & 0.87 & 2.1 & 0.33 & 1.2 & 2.43 & 13.6 & 72.5 \\
\hline & 7 & $(10-20)$ & 4.15 & 0.9 & 18 & 0.21 & 0.03 & 0.87 & 1.9 & 0.29 & 1.16 & 2.19 & 13.2 & 75 \\
\hline & 8 & $(10-20)$ & 4.13 & 1.2 & 25 & 0.25 & 0.07 & 1.16 & 2.4 & 0.38 & 1.54 & 2.78 & 13.7 & 75.3 \\
\hline \multirow{4}{*}{$\begin{array}{l}\text { Concave } \\
\text { Slope }\end{array}$} & 9 & $(10-20)$ & 4.05 & 1.4 & 14 & 0.23 & 0.05 & 0.96 & 1.7 & 0.32 & 1.28 & 2.02 & 15.8 & 75 \\
\hline & 10 & $(10-20)$ & 4.18 & 1.1 & 17 & 0.21 & 0.04 & 0.87 & 1.6 & 0.29 & 1.16 & 1.89 & 15.3 & 75 \\
\hline & 11 & $(10-20)$ & 4.08 & 1.6 & 21 & 0.25 & 0.06 & 1.16 & 2.4 & 0.36 & 1.52 & 2.76 & 13 & 76.3 \\
\hline & 12 & $(10-20)$ & 3.96 & 1.4 & 18 & 0.24 & 0.05 & 1.35 & 2.4 & 0.34 & 1.69 & 2.74 & 12.4 & 79.9 \\
\hline \multirow{4}{*}{$\begin{array}{l}\text { Concave } \\
\text { Slope }\end{array}$} & 13 & $(10-20)$ & 3.98 & 1.2 & 20 & 0.23 & 0.05 & 1.45 & 3 & 0.33 & 1.78 & 3.33 & 9.9 & 81.5 \\
\hline & 14 & $(10-20)$ & 4.02 & 1.1 & 19 & 0.21 & 0.04 & 1.16 & 2.4 & 0.3 & 1.46 & 2.7 & 11.1 & 79.5 \\
\hline & 15 & $(10-20)$ & 4.03 & 1.9 & 33 & 0.27 & 0.1 & 2.02 & 4.3 & 0.45 & 2.47 & 4.75 & 9.5 & 81.8 \\
\hline & 16 & $(10-20)$ & 4.04 & 1 & 21 & 0.23 & 0.06 & 1.64 & 3.5 & 0.34 & 1.98 & 3.84 & 8.9 & 82.8 \\
\hline
\end{tabular}


The hill top is associated with dystrophic yellow latosol that contains strongly drained soils with clay texture. These soils were found on the highest heights and least sloping topography, characterizing a dystrophic environment that is richer in organic carbon, with high exchangeable Al contents in the deeper layers $(30-50 \mathrm{~cm}, 50-70 \mathrm{~cm}$ and $70-100 \mathrm{~cm})$. It is important to note that both the low ramp as well as the lower and upper slopes had been formed by colluvial sediments originated from the highest altitudes, or from the saprolites exposed by erosion.

The levels of $\mathrm{Ca}^{2+}$ and $\mathrm{Mg}^{2+}$ in the Cambisols of the low ramp were significant and highest, therefore the values of the sum of bases (SB) and base saturation (V) as well as the $\mathrm{pH}$ were the highest and equilibrium phosphorus levels considerably high.
In the lower and upper slopes, the $\mathrm{pH}$ of the Cambisols was high, though lower than in the low ramp. The levels of $\mathrm{Ca}^{2+}$ and $\mathrm{Mg}^{2+}$ were low, which resulted in a base saturation (V) of less than $40 \%$, so the soil was characterized as dystrophic, but alic, due to the low exchangeable Al content.

The top range (dystrophic yellow Latosol) was characterized by strong acidity and low levels of $\mathrm{P}$, $\mathrm{K}$ and $\mathrm{Ca}^{2+}$, which conferred low levels of SB and V. The Al saturation levels ( $\mathrm{m}$ ) were also the highest, due to the higher absolute value of exchangeable Al, but with very high levels of OM that can complex exchangeable Al.

In summary, if the values of SB and V were used as markers of the soil nutritional status, they would

Table 3 - Scores of arboreal species sampled with more than 5 individuals (abbreviated names) over a geomorphologic gradient under Submontane, semideciduous forest (Mata do Mumbaça, Dionísio, Minas Gerais State).

Tabela 3 - Escores das espécies arbóreas amostradas (com 5 ou mais indivíduos) em um gradiente topográfico de uma Floresta Estacional Semidecidual Submontana, Mata do Mumbaça, Dionísio-MG, e respectivos nomes abreviados.

\begin{tabular}{|c|c|c|c|}
\hline Species & $\begin{array}{l}\text { Short } \\
\text { Name }\end{array}$ & $\begin{array}{l}\text { Scores Axes I } \\
(10-20 \mathrm{~cm})\end{array}$ & $\begin{array}{c}\text { Scores Axes II } \\
(10-20 \mathrm{~cm})\end{array}$ \\
\hline Acacia polyphylla DC. & Acac poly & 1.94 & 2.09 \\
\hline Aniba firmula (Nees \& C. Mart.) Mez & Ani firm & 0.71 & 0.38 \\
\hline Apuleia leiocarpa (Vogel) J.F. Macbr. & Apu lei & 0.99 & 2.41 \\
\hline Astronium fraxinifolium Schott ex Spreng. & Astr frax & 1.25 & -1.29 \\
\hline Casearia arborea (Rich.) Urb. & Cas arb & -0.66 & -0.19 \\
\hline Erythroxylum sp. & Eryt pel & -0.87 & 0.08 \\
\hline Jacaranda macrantha Cham. & Jac macr & 0.38 & -1.71 \\
\hline Lacistema pubescens Mart. & Lac pub & -0.81 & -0.36 \\
\hline Lecythis lurida (Miers) S.A. Mori & Lecy lur & 1.81 & -1.29 \\
\hline Licania octandra (Hoffmanns. ex Roem. \& Schult.) Kuntze & Lica oct & -0.89 & 0.16 \\
\hline Machaerium brasiliense Vogel & Mach brás & 1.86 & -1.57 \\
\hline Matayba elaeagnoides Radlk. & Mat elae & -1.21 & -0.06 \\
\hline Miconia calvescens DC. & Mic calv & -0.89 & 0.88 \\
\hline Miconia sellowiana Naudin & Mic sell & 0.11 & -0.41 \\
\hline Miconia urophylla DC. & Mic uro & -0.39 & 2.15 \\
\hline Myrcia fallax (Rich.) DC. & Myr fal & -0.54 & 0.95 \\
\hline Myrcia rufipes DC. & Myr ruf & 1.03 & -0.42 \\
\hline Myrcia tijucensis Kiaersk. & Myr tij & 0.56 & -0.12 \\
\hline Newtonia contorta (DC.) Burkart & New cont & -0.41 & 1.21 \\
\hline Pera leandri Baill. & Per lean & 0.68 & -0.97 \\
\hline Pouteria torta (Mart.) Radlk. & Pout tor & 1.26 & -0.15 \\
\hline Pouteria venosa (Mart.) Baehni & Pout vê & 1.45 & 2.78 \\
\hline Siparuna guianensis Aubl. & Sip guia & -0.15 & -0.11 \\
\hline Swartzia apetala Raddi & Swa ape & 1.08 & -1.61 \\
\hline Tapirira guianensis Aubl. & Tap guia & -1.18 & 0.97 \\
\hline Xylopia aromatica (Lam.) Mart. & Xyl aro & -0.85 & -0.54 \\
\hline Xylopia sericea A. St.-Hil. & Xyl ser & 0.01 & 0.002 \\
\hline
\end{tabular}

Revista Árvore, Viçosa-MG, v.36, n.4, p.707-718, 2012 
indicate an ascending fertility gradient from the hill top to the upper concave slop and from the lower concave slope to the low ramp.

The environmental heterogeneity, reflected in the different soils classes, is related to the geomorphological gradient underlying the area. At the top of the area, with less slope, is the dystrophic Yellow Latosol, where there are more leached soils with impoverished nutrient content, due to a more advanced pedogenesis (EMBRAPA, 1999), apart from the more marked drainage, resulting in an extremely oligotrophic environment, acid and rich in $\mathrm{Al}^{3+}$.

The leaching and stability of the former erosion surface can explain the destruction of easily weatherable primary minerals of the Dystrophic Yellow Latosol at higher altitudes and clay formation (mainly of kaolinite) was a consequence.

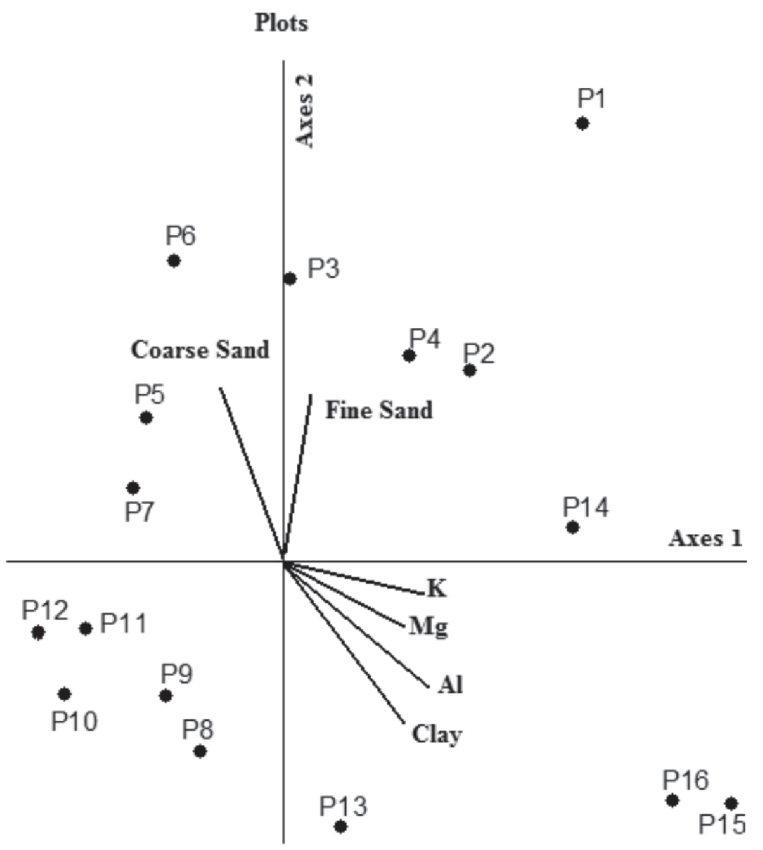

The existence of an environment that is a little richer in areas of low ramps is given by the accumulation of younger colluvial soil, where saprolite is closer to the surface.

With regard to the chemical and physical properties, it was observed that few environments had a positive regression with the variables studied, while in general, most nutrients were highly correlated with OM, including $\mathrm{Ca}+\mathrm{Mg}, \mathrm{SB}, \mathrm{K}, \mathrm{pH}, \mathrm{Al}$ and $\mathrm{P}$.

The levels of available P extracted by Mehlich were correlated with $\mathrm{OM}$ in all topographic ranges, particularly in the horizons $\mathrm{A}(0-20 \mathrm{~cm})$ and $\mathrm{B}(30-50 \mathrm{~cm})$. It is noteworthy that the regression between these two variable, $\mathrm{P}$ and $\mathrm{OM}$, was perfect and positive $\left(r^{2}=1\right)$ in the lower and upper concave slope at depths of $0-20 \mathrm{~cm}$ and $30-50 \mathrm{~cm}$.

Figure 1 - Diagram showing the ordination of plots and species after canonical correspondence analysis in subsurface soil $(10-20 \mathrm{~cm})$, based on the distribution of arboreal species density in 16 plots under Submontane, semideciduous forest (Mata do Mumbaça, Dionísio, Minas Gerais State). The plots and species are represented by the corresponding number, whereas the edaphic variables are represented by vectors where the species are shown by abbreviated names (Table 3).

Figura 1 - Diagrama mostrando a ordenação das parcelas e espécies após a análise de correspondência canonical na camada superficial do solo (10-20 cm), baseado na distribuição da densidade de espécies arbóreas em 16 grupos sob Floresta Semidecidual Submontana (Mata do Mumbaça, Dionísio, Estado de Minas Gerais). Os grupos e espécies são representados pelo número correspondente, enquanto as variáveis edáficas são representadas pelos vetores onde as espécies são mostradas pelos nomes abreviados (Tabela 3). 
The values of silt and sum of bases (SB) in the $0-20 \mathrm{~cm}$ layer were highly correlated in all topographical segments, but the $\mathrm{r}^{2}$ values were negative. The values of $\mathrm{pH}$ and $\mathrm{OM}$ are clearly correlated in the surface soils $(0-20 \mathrm{~cm}$ and $30-50 \mathrm{~cm})$ of the lower concave slope.

Low correlations were found in the $0-20 \mathrm{~cm}$ surface layer between the variables $\mathrm{Ca}+\mathrm{Mg}$ x Clay and SB $\mathrm{x}$ clay whereas $\mathrm{Ca}+\mathrm{Mg}$ x OM were well correlated in all environments. The silt and $\mathrm{K}$ levels in the deep low ramp $(70-100 \mathrm{~cm})$ and deep upper slope $(30-50 \mathrm{~cm})$ were zero, in other words, these two variables did not depend on each other, opposite to what occurs when the silt levels correspond to higher concentrations of micas and primary minerals with potassium.

\section{DISCUSSION}

\subsection{Physicochemical soil characterization}

It appears that the soils are poor, with high Al levels and low base saturation (ALVAREZ V. et al., 1999). The occurrence of forest vegetation in dystrophic soils suggests that the replacement of nutrients depends on an efficient cycling strategy (RODRIGUES et al., 1989).

Levels of $\mathrm{P}, \mathrm{K}, \mathrm{Ca}$, and $\mathrm{Mg}$ gradually increased from the hill top to the low ramp. This shows a slightly higher chemical fertility in the soil of the low ramp compared to the poorer soil leached from the top (MARTINS et al., 2003). Along soil geomorphological gradients, soil fertility normally increases from the top to the low ramp, and these variations are related to the removal of material from the higher and their deposition in the lower parts (RESENDE et al., 1995; BOTREL et al., 2002; MARTINS et al., 2003).

The results agree with the known chemical pattern of soils in the region of Zona da Mata - MG, where soils in higher landscape positions are dystrophic, with higher Al levels, while the slopes and flat land are more fertile and less acid (CÔRREA, 1983; CARVALHOFILHO, 1989; KER; SCHAEFER, 1995; MARTINS et al., 2003).

\subsection{Ordination of soil and vegetation data}

According to BOTRELet al. (2002) and to MARTINS et al. (2003), plots installed in positions lowered and the lower third of the slope are correlated with sandy soil and with higher concentrations of $\mathrm{P}, \mathrm{K}, \mathrm{Ca}$ and
MG. On the opposite side of axis 1, plots of topographic positions the upper third of the slope and top soil are correlated with more clay soils, poor in nutrients and with higher aluminum content.

As mentioned above, the first two axes explained approximately $31 \%$ (axis 1) and $30 \%$ (axis 2) of the total variance of the data, indicating that the floristic variables contains a lot of noise, i.e, a high proportion of not explained variance, which is very common in vegetation data (TER BRAAK, 1987). But these values can be considered intermediate compared with similar studies conducted in seasonal semideciduous forest in southern Minas Gerais (BOTREL et al., 2002) and in the Zona da Mata, Minas Gerais (MARTINS et al., 2003), indicating the existence of a environmental gradient where some species are restricted to certain plots along it.

Among these, Astronium fraxinifolium, which occurs in different forest formations and the Cerrado (Brazilian savanna), is considered a generalist species (RIZZINI, 1963), in other words, it is adapted to poor soils as well. In this study the species Xylopia sericea was found in the upper concave slope, as confirmed in the study of (MARTINS et al., 2003).

This group of species adapted to more selective edaphic conditions, e.g., high acidity and very low fertility, could be used in forest restoration projects of degraded areas, mainly in slopes and hill tops covered with degraded pastures (MARTINS et al., 2003).

Pouteria venosa, Apuleia leiocarpa, Siparuna guianensis, Newtonia contorta, Licania octandra, Myrcia fallax, Miconia calvescens and Tapirira guianensis have been sampled frequently in floristic phytosociological surveys carried out in seasonal semideciduous forest, particularly the genera Apuleia, Siparuna, Myrcia and Tapirira, which can be recommended for forest restoration in these environments (BOTREL et al. 2002; LOPES et al., 2002; MARTINS et al., 2003).

According to (MARTINS et al., 2003) the content and aluminum saturation increased significantly from low ramp to the top.

The set of results confirm the considerations of (CLARK, 2002) and (MARTINS et al., 2003), on the relationship between edaphic factors and vegetation, which highlight the role of topography and edaphic factors in determining species distribution. 


\subsection{Analysis of environmental variables and the Pearson Correlation (r)}

Ranges of dystrophic Cambisols, dystrophic Haplic Cambisols and dystrophic Yello Latosol, these are areas of intense mass movement, where thick colluvia burying previous soil levels are not uncommon, as described by (FERREIRA JR. et al., 2007).

According to (RESENDE et al., 1988), the formation of an increasing nutrient gradient and water content in the direction top to base is common in soils with steep topography. This gradient is a result of the effect of topography on the factor time in soil formation, as controller of the period of exposure to bioclimatic agents (climate and organisms), as observed by (RESENDE et al., 1997). These authors claim that older soils (longer exposure time to weathering agents) are located on the highest surfaces with smooth surface, while younger soils are located in the most rejuvenated parts of the landscape, which are exactly the lower and sometimes more rugged areas.

In these younger soils, in agreement with (RESENDE et al., 1988, 1997; 2002) and Guerra and (CUNHA, 1996), natural fertility tends to be higher, the clay fraction activity increased (cation exchange capacity), the amount of easily wheatherable primary minerals larger and silt content higher, as opposed to the soils in high positions, which are more weathered by the high pedogenetic age, deep, porous and with lower natural fertility. These more weathered soils act as a great $\mathrm{P}$ drain, where most soil $\mathrm{P}$ is adsorbed to iron and aluminum oxides and recalcitrant organic matter in forms unavailable in the short term (NOVAIS; SMYTH 1999; MCGRATH et al., 2001; RESENDE et al., 1997).

According to (NOVAIS; SMYTH, 1999), with increasing weathering degree, gradual changes in the soil characteristics make it electropositive, causing a drop of the ECEC (effective cation exchange capacity) and reduced base saturation, while gradually increasing the retention of anions such as phosphate, making the soils acid, leached and very P-poor.

The previous weightings explain the low nutrient levels in the dystrophic Latossolo Amarelo (Top) and the high values of potential acidity $(\mathrm{H}+\mathrm{Al})$ and exchangeable ( $\mathrm{Al}), \mathrm{Al}$ saturation $(\mathrm{m})$, as well the strongly acidic character (EMBRAPA, 1999). They also explain the low $\mathrm{P}$ content in the four soil classes, confirming the statement of Resende et al., (1988) that P deficiency is high in $65.1 \%$ of the tropical soils and moderate in 26.6\%. According to (RESENDE et al., 1988) and (RAVEN et al., 2001), the plant demand for P is much lower than for nitrogen $(\mathrm{N})$ and potassium $(\mathrm{K})$.

(RESENDE et al., 2002) formulated the principle that in essence, plants need sunlight, water and nutrients and that these factors form the basic environmental triangle, while the other factors - soil class, relief, geological substrate and so on, are supporting factors and should therefore be interpreted in terms of resources of radiation, water and nutrients. This concept shows how the heterogeneity of the abiotic environment creates locally differentiated conditions which affect the vegetation, influencing ecological aspects.

One aspect related to conservation and restoration of forest formations of the Mata Atlântica is the presence of environments considered unstable in terms of erosion and nutrient loss. According to (RESENDE et al., 2002), the low nutrient resource in poor soils with shallow solum (horizon $\mathrm{A}+\mathrm{B}$ ), is maintained under natural vegetation, by the process of nutrient cycling. When the native vegetation is removed, this process is minimized, causing significantly increased nutrient losses.

Since a great part of the Atlantic Forest biome, particularly in the Southeast, is characterized by the hilly relief called "Mares de Morros", the depletion of the dystrophic soil of these regions is aggravated by the predominance of the so-called steep landforms, on the edges of amphitheater-like ravines, which are typical of this strongly hilly relief. The term "Mares de Morros" was, according to (MAIO, 1980), coined by Deffontaines to designate the morphology of the landscape dominated by convex elevations in the shape of a "half orange", resulting from fluvial dissection and physicochemical weathering of the rocks of the Precambrian crystalline mass.

\section{CONCLUSIONS}

The pedological and topographic gradient was characterized by alterations in physicochemical soil properties; the $10-20 \mathrm{~cm}$ soil layer in the low ramp were more sandy, slightly more fertile and less acid compared with the hill top, where the soil was more clay, nutrientpoor and highly acidic. The conditions in the same soil layers in the lower and upper slope, in turn, were intermediate. $\mathrm{P}$ levels were limiting in all soils.

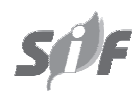

Revista Árvore, Viçosa-MG, v.36, n.4, p.707-718, 2012 
The species distribution along the topographic gradient was associated with changes in chemical fertility, acidity and soil texture.

\section{REFERENCES}

ALVAREZ V., V. H. et al. Interpretação dos resultados das análises de solos. In: RIBEIRO, A. C.; GUIMARÃES, P. T. G.; ALVAREZ V., V. H. Recomendações para o uso de corretivos e fertilizantes em Minas Gerais. Viçosa, MG: CFSEMG, 1999. p.25-32.

BORTOLUZZI, R. L. C. et al. Leguminosae, Papilionoideae no Parque Estadual do Rio Doce, Minas Gerais, Brasil. II: Árvores e arbustos escandentes. Acta Botânica Brasílica, v.18, n.1, p.49-71, 2004.

BOTREL, R. T. et al. Influência do solo e topografia sobre as variações da composição florística e estrutura da comunidade arbóreoarbustiva de uma floresta estacional semidecidual em Ingaí, MG. Revista Brasileira de Botânica, v.25, n.1, p.195-213, 2002.

CARVALHO, D. A. et al. Variações florísticas e estruturais do componente arbóreo de uma floresta ombrófila alto-montana às margens do Rio Grande, Bocaina de Minas, MG, Brasil. Acta Botânica Brasília, v. 19, n.1, p.91-109, 2005.

CARVAlHO-FILHO, A. Caracterizações mineralógica, química e física de solos de duas unidades de paisagem do Planalto de Viçosa. Viçosa, MG: Universidade Federal de Viçosa, 1989.

CLARK, D.B. Los fatores edáficos y la distribución de las plantas. In: GUARIGUATA, M. R.; KATtAN, G. H., (Eds.) Ecologia y conservatión de bosques neotropicais. Cartago: LUR, 2002. p.193-221.

CORRÊA, G. F. Modelo de evolução e mineralogia da fração argila de solos do Planalto de Viçosa. Viçosa, MG: Universidade Federal de Viçosa, 1983.

DRUMOND, M. A.; MEIRA NETO, J. A. A. Composicões florística e fitossociológica de uma mata secundária de um trecho de Mata Atlântica. Ciência Rural, v.29, n.4, p.657-661, 1999.
DURIGAN, G.; RODRIGUES, R. R.; SCHIAVINI, I. A heterogeneidade ambiental definindo a metodologia de amostragem da floresta ciliar. In: RODRIGUES, R. R.; LEITÃO FILHO, H. F. (Eds.). Matas ciliares: conservação e recuperação. São Paulo: EDUSP, 2000. p.159-167.

EMPRESA BRASILEIRA DE PESQUISA AGROPECUÁRIA - EMBRAPA. Centro Nacional de Pesquisa de Solos. Manual de métodos de análise de solos. Rio de Janeiro: 1997. 212p.

EMPRESA BRASILEIRA DE PESQUISA AGROPECUÁRIA - EMBRAPA. Centro Nacional de Pesquisa de Solos. Sistema brasileiro de classificação de solos. Rio de Janeiro: 1999. 412p.

ESPÍRITO-SANTO, F. D. B. et al. Variáveis ambientais e a distribuição de espécies arbóreas em um remanescente de floresta estacional semidecídua montana no campus da Universidade Federal de Lavras, MG. Acta Botânica Brasílica, v.16, n.3, p.331-356, 2002.

FERREIRA JR., W. G. et al. Influence of soils and topographic gradients on tree species distribution in a Brazilian Atlantic Tropical Semideciduous Forest. Edinburgh Journal of Botany, v.64, n.2, p.137-157, 2007.

GAUCH, H. G. J. Multivariate analysis in community ecology. Cambridge: Cambridge University Press, 1982. 298p.

GILHUIS, J. P. Vegetation survey of the Parque Florestal Estadual do Rio Doce, MG, Brasil. Wageningen: Agricultural University Wageningen, 1986. 112p.

GUERRA, A. J. T.; CUNHA, S. B.

Geomorfologia e meio ambiente. Rio de Janeiro: Bertrand Brasil, 1996. 334p.

KER, J. C.; SCHAEFER, C. E. R. Roteiro da excursão pedológica Viçosa-Sete Lagoas. Viçosa, MG: Sociedade Brasileira de Ciência do Solo/EMBRAPA/CNPS, 1995.47p.

LOMBARDI, J. A.; GONÇALVES, M. Composição florística de dois remanescentes de Mata Atlântica do sudeste de Minas Gerais, Brasil. Revista Brasileira de Botânica, v.23, n.3,p.255-282, 2000. 
LOPES, W. P. et al. Composição da flora arbórea de um trecho de floresta estacional no Jardim Botânico da Universidade Federal de Viçosa (face sudoeste), Viçosa, Minas Gerais. Revista Árvore, v.26, n.3, p. 339-347, 2002.

MAIO, C. R. Geomorfologia do Brasil: fotos e comentários. Rio de Janeiro: IBGE, 1980. 305p.

MARTINS, S. V. et al. Distribuição de espécies arbóreas em um gradiente topográfico de Floresta Estacional Semidecidual em Viçosa, MG.

Scientia Forestalis, v.64, p.172-181. 2003.

MCCUNE, B.; MEFFORD, M. J. PC-OR. version 4.14. Multivariate analysis of ecological data. Glaneden Beach: MjM Software Design, 1999. 237p.

MCGRATH, D. A.; DURYEA, M. L.; CROPPER, W. P. Soil phosphorus availability and fine root proliferation in Amazoniam agroforest 6 years following forest conversion. Agriculture, Ecosystems and Environment, v.83, n.3, p.271-284, 2001.

MUELLER-DOMBOIS, D.Y.; ELLENBERG, M. Aims and methods in vegetation ecology. New York: John Wiley \& Sons, 1974. 547p.

NEWTON, A. C. Forest ecology and conservation: a handbook of techniques. Oxford: Oxford University Press, 2007. 480p. (Techniques in Ecology and Conservation)

NOVAIS, R. F.; SMYTH, T. J. Fósforo em solo e planta em condições tropicais. Viçosa, Mg: Sociedade Brasileira de Ciência do Solo, 1999.399p.

OLIVEIRA FILHO, A. T. et al. Estrutura fitossociológica e variáveis ambientais em um trecho de mata ciliar do córrego Vilas Boas, Reserva Biológica do Poço Bonito, Lavras (MG). Revista Brasileira de Botânica, v.17, n.1, p. $67-85,1994 a$.

OLIVEIRA FILHO, A. T.; SCOLFORO, J. R.; MELLO, J. M. Composição florística e estrutura comunitária de um remanescente de floresta semidecídua montana em Lavras, MG. Revista Brasileira de Botânica, 17, n.1, p.167-182, 1994b.
OLIVEIRA FILHO, A. T. et al. Effects of canopy gaps, topography, and soils on the distribution of woody species in a Central Brazilian Deciduous Dry Forest. Biotropica, v.30, n.3, p.362-375, 1998.

RAVEN, P. H.; EVERT, R. F.; EICHHORN, S. E. Biologia vegetal. Rio de Janeiro: Guanabara Koogan, 2001. 906p.

RESENDE, M.; CURI, N.; SANTANA, D. P. Pedologia e fertilidade do solo: interações e aplicações. Brasília: MEC/ESAL/ POTAFOS, 1988. 84p.

RESENDE, M. et al. Pedologia: base para distinção de ambientes. Viçosa, MG: Núcleo de Estudo de Planejamento e Uso da Terra, 1995. 304p.

RESENDE, M. et al. Pedologia: base para distinção de ambientes. Viçosa, MG: Núcleo de Estudo de Planejamento e Uso da Terra, 1997. 334p.

RESENDE, M.; LANI, J. L.; REZENDE, S. B. Pedossistemas da Mata Atlântica: considerações pertinentes sobre a sustentabilidade. Revista Árvore, v.26, n.3, p.261-269, 2002.

RIZZINI, C. T. A flora do cerrado. Análise florística das savanas centrais. In: SIMPÓSIO SOBRE O CERRADO, 1963, São Paulo. Anais... São Paulo: 1963. p.126-177.

ROCHA, C. T. V. et al. Comunidade arbórea de um continuum entre floresta paludosa e de encosta em Coqueiral, Minas Gerais, Brasil. Revista Brasileira de Botânica, v.28, n.2, p.203-218, 2005.

RODRIGUES, R. R. et al. Estudo florístico e fitossociológico em um gradiente altitudinal de mata estacional mesófila semidecídua na Serra do Japi, Jundiaí, SP. Revista Brasileira de Botânica, v.12, n.1, p.71-84, 1989.

RODRIGUES, L. A. et al. Efeitos de solos e topografia sobre a distribuição de espécies arbóreas em um fragmento de floresta estacional semidecidual, em Luminárias, MG. Revista Árvore, v.31, n.1, p.25-35, 2007.

Revista Árvore, Viçosa-MG, v.36, n.4, p.707-718, 2012 
ROYAL BOTANIC GARDENS. Index

Kewensis on compact disc - manual.

Oxford: Oxford University Press, 1993.67p.

SOUZA, J. S.; LORENZI, H. et al. Botânica sistemática: guia ilustrado para identificação das famílias de Angiospermas da flora brasileira, baseado em APG II. Nova Odessa: Instituto Plantarum, 2005.704p.

TER BRAAK, C. J. F. The analysis of vegetationenvironment relationships by canonical correspondence analysis. Vegetation, v.69, n.1, p.69-77, 1987.
TER BRAAK, C. J. F. Ordination. In: JONGMAN, R. H. G.; TER BRAAK, C. J. F.; van TONGEREN, O.F.R. (Eds.) Data analysis in community and landscape ecology. New York: Cambridge University Press, 1995. p.91-173.

VELOSO, H. P.; RANGEL FILHO, A. L. R.; LIMA, J. C. A. Classificação da vegetação brasileira adaptada a um sistema universal. Rio de Janeiro: Fundação Instituto Brasileiro de Geografia e Estatística, 1991.124p. 